\title{
Understanding the signature pedagogy of the design studio and the opportunities for its technological enhancement
}

\author{
Phillip Crowther \\ School of Design \\ Queensland University of Technology \\ p.crowther@qut.edu.au
}

\begin{abstract}
This paper presents an analysis of the studio as the signature pedagogy of design education. A number of theoretical models of learning, pedagogy, and education are used to interrogate the studio for its advantages and shortcomings, and to identify opportunities for the integration of new technologies and to explore the affordances that they might offer. In particular the theoretical ideas of signature pedagogies, conversational frameworks, and pedagogical patterns are used to justify the "unique" status of the studio as a dominant learning environment and mode of delivery within design education. Such analysis identifies the opportunities for technological intervention and enhancement of the design studio through a re-examining of its fundamental pedagogical signature. This paper maps the dimensions and qualities that define the signature pedagogy against a range of delivery modes and technological media forms. Through such investigation it seeks to identify appropriate opportunities for technology; in essence offering a structure or framework for the analysis of future enquiry and experimentation.
\end{abstract}

Keywords

Design, studio, signature pedagogy, learning design, pedagogical pattern, technology

\section{Design education and the studio}

Architectural education is based primarily around the design studio as a pivot and gathering point of all knowledge and skill accreted throughout the curriculum

(Mostafa \& Mostafa, 2010, p. 310).

While the design studio is a widely used learning environment in design education, this paper will draw heavily on research into the architectural studio as an example because it has received most attention in existing research in this field. Architectural education has a long history, developed over centuries from an historic model of apprenticeship. That model of master and student still dominates architectural education and is replicated in formal education though the ubiquitous mode of the studio. Within the design professions the term "studio" is used rather loosely to both describe a physical space (the actual place in which the learning and teaching activities take place) and also the mode of engagement (as a pedagogical strategy). To complicate matters further, the term is also used by the profession to describe the place of work activity. It is synonymous with the idea of the workplace of an artist, as in the artist's studio. The educational studio attempts to 
replicate this professional incarnation of the studio in many ways. In this paper, I use the term "studio" to refer to the place of learning as an amalgam of both the physical space and the cultural and pedagogical activities.

The contemporary learning studio is not dissimilar to the studio of the French Royal Academy or the École des Beaux-Arts of the nineteenth century (Bender \& Vredevoogd, 2006). This design studio is universally seen as the most unique and important of the places or activities in an architecture course and is often referred to as the place where knowledge and skills from the areas are integrated and applied (Stevens, 1998). Design studios universally apply the semi-structured learning strategy of experiential leaning; in particular, the project (Delahaye, 2005) which includes some aspects of the learning strategy of problem-based learning. In practice, this mode of delivery seeks to create a learning environment in which students work on design projects while tutors offer formative feedback in the form of individual reviews given casually at weekly classes. Much of the learning takes place through dialogue that elicits those activities that shape, elaborate, and deepen understanding (Biggs, 1999; Schön, 1984).

Design studios are remarkably similar across the industrialised world. Typically students will attend the studio where an academic gives instruction. This usually occurs in small groups of from 12 to 20 students for a period of time from half a day to two days a week. Students will engage in simulated real world activities of designing an artefact to a given brief, and will respond to weekly feedback given by the academic. The project of designing is in itself usually the major component of the assessment activity of the studio. The semester of study typically culminates in a public presentation of the design project, referred to as a crit, at which time it is assessed by a jury of academics (Bender \& Vredevoogd, 2006). The physical space of the studio is characterised by a lack of formality; no front of the classroom, movable furniture, desks for drawing and drafting, spaces for model making, computers, projection screens, and space for presenting drawings and models during crits. The aim is to support a flexible pedagogy through flexible physical infrastructure (Taylor, 2008).

This flexible pedagogy is in response to the flexible nature of the design process itself, in which there is no single correct answer. While the pedagogical activities of the design project are basically linear, with the inclusion of repeatable loops, it should not be taken to infer that there is a pre-determined ending point. Indeed, especially in design, "learning cannot be pre-determined by teaching" (Rohse \& Anderson, 2006, p. 82). This studio mode of learning accepts uncertainty, serendipity and happenstance as part of the nature of education, wherein the solutions are intentionally incomplete.

\section{Advantages of studio mode}

The advantages that the studio mode of delivery offers are many, and can be seen to align with accepted good practice in higher education (Biggs, 1996). The design studio does not lend itself to surface approaches to learning neither do the assessment techniques typically used. These rather support a deep approach in which "the student is directed towards the intentional content of the learning material” (Marton \& Säljö, 1976, p. 7). The activities of the studio, in which a student is asked to create a new design, cannot be engaged with in a reproductive way with a shallow approach. The activities explicitly require the creation of an original design; a process in which students must analyse the context and synthesise that understanding with a range of theories and concepts to develop their own understandings; and to effectively create their own learning experiences. Students must necessarily comprehend the subject and transfer understanding to a new context, and in doing so exhibit that they are "learning as seeing something in a different way" (Marton, Dall'Alba, \& Beaty, 1993, p. 290). Since studio activities are also the assessment tasks, they can be seen to align with the expected learning outcomes of learning to design. The assessment task, through the expectation that students will synthesis new concepts in a new context, establishes a learning environment in which "meaning is created by the learner" (Biggs, 1999, p.30): this constructivist approach to education and learning places the focus heavily on the leaning activity. 
The complex and flexible nature of studio education can be seen to accommodate three types of learning:

- $\quad$ learning about design (the development of knowledge);

- learning to design (the development and application of skills) (Schön, 1984); and,

- learning to become an architect (the transformative pedagogy in which learning is identified as changing as a person) (Dutton, 1987).

The studio provides an environment that facilitates all of these learning scenarios by embodying a theory of "teaching as making leaning possible" and allowing academics to work "cooperatively with learners to help them change their understanding" (Ramsden, 2003, p. 110).

\section{Shortcomings of studio mode}

Much of the activity of the studio centres on dialogue between student and tutor. In the case of architecture, and to a lesser extent in other disciplines, this attempts to replicate the activities and relationships of a professional practice office. The privileged position of the academic, this "principal social relationship... between studio tutor and student" (Nicol \& Pilling, 2000, p. 8), also carries with it a strong aspect of socialisation and acculturation. There is a "hidden curriculum [of] unstated values, attitudes, and norms which stem tacitly from the social relations" (Dutton 1987 , p. 16). This hidden curriculum relocates students in social space and acts as a significant force in them becoming an architect (Stevens, 1998). It is that part of the master and apprentice relationship that is seldom discussed, but which bears heavily on the emotional and psychological development of the student. Unfortunately in many schools of architecture, this relationship is still based on an outdated nineteenth century hierarchical model of academia.

This outdated learning environment, and its hidden curriculum, favours coercion over dialogue, seeks to maintain the status quo, and fails to address the possibilities of a more diverse future that will incorporate a greater diversity of technological enhancements (Groat \& Ahrentzen 1996; Mewburn, 2011). The place in which this hidden curriculum is most evident is in the public presentations at the end of the semester; the assessment activity of the crit (the final presentation and critique of the student project work). As noted, the crit is a curious blend of assessment activity and learning activity widely used in design education, though its value as a technique for either has been seriously questioned by some researchers in recent years, which has prompted others to investigate alternative modes of reviewing student projects (Brindley, Doidge, \& Willmott, 2000). This somewhat antiquated mode of dialogue is overdue for technological intervention.

\section{Signature pedagogies}

These advantages, affordances, and shortcomings of the studio are not exclusive to the discipline of architecture. The studio is used everywhere in schools of design as the foundational mode of instruction and education. Such ubiquitous forms of teaching and learning, which are associated with particular professions, have been researched by Shulman (2005) and come to be referred to as signature pedagogies. The notion of signature pedagogies, as a type of learning design for a particular profession, has been supported by other notable researchers in the field. Laurillard (2012) references the term arguing that "the best teaching ideas are most likely to be developed in very specific subject matter contexts. They have been referred to as the 'signature pedagogies' of a discipline" (p. 220).

Shulman's ideas about signature pedagogies are remarkably well aligned with the previously cited pedagogical theories of Schön (1984) and Dutton (1987), in that they include the dimensions of being able to think and act with integrity as a professional (Shulman, 2005); which are in effect those dimensions of knowing about design, being able to design, and becoming a professional. Shulman (2005) also identifies three further dimensions that characterise a signature pedagogy: 
(a) a surface structure of operational acts of teaching and learning, (b) a deep structure of assumptions about how best to impart knowledge and skills, and (c) an implicit structure as a set of beliefs, values, and attitudes. This third dimension is referred to as the "hidden curriculum" (p. 55). Again, these three are clearly relevant to the design studio. Two further features of signature pedagogies that are clearly evident in design studios are those of uncertainty and of public student performance. As previously noted, the act of designing is always an act of uncertainty and, as such, the design studio is an environment of unpredictability and serendipity. It is also, critically, a social environment in which students are expected to present their work to their peers and to academics for discussion, review, and assessment.

While signature pedagogies may represent the best teaching ideas from particular profession, they are not without problems. The routine of such approaches can provide valuable scaffolding to students, but can also result in rigidity, and lack or responsiveness to changing contexts. This is noted when approaches "persist even when they begin to lose their utility, precisely because they are habits with few countervailing forces" (Shulman, 2005, p. 56).

As a means of moving on, Shulman (2005) has offered that:

New technologies of teaching via the Internet; Web-based information seeking; computer-mediated dialogue; collaborations and critiques in the design studio; powerful representations of complex and often unavailable examples of professional reasoning, judgment, and action - all create an opportunity for re-examining the fundamental signatures we have so long taken for granted. (p. 59)

\section{The signature of the design studio}

The above review and analysis of the studio alludes to a situation in which the studio is no longer working effectively and there is a need for it to be re-examined in the light of the availability of new technologies. Using Shulman's (2005) dimensions of a signature pedagogy, we can identify the characteristics of the design studio that make it both unique and ubiquitous, with a view to identifying opportunities for the integration of new technologies. Schulman further identifies the studio as the "signature of design," though offers only limited description of the characteristics of that signature. They are based on his three dimensions of pedagogy and are physical, organisational, and attitudinal. They include: the lack of a front to the classroom, experimentation, collaboration, practising of skills, a focus on an artefact, dialogue, instruction and critique. This list however goes only part of the way to explaining the signature.

Shreeve, Sims, and Trowler (2010) identified a number of characteristics of the studio as a signature pedagogy; they also support the philosophy of the studio as a place for learning through problem-based learning and through project work. Their analysis of multiple case studies identifies the following characteristics or aspects to the signature pedagogy: learning by doing and acting it out, experiential learning, uncertainty, visible dimension, public performance, social, focus on process, and the physical studio spaces itself.

Similarly, Shrand and Eliason (2011) investigated aspects of the signature pedagogy of the studio with a view to identifying practices that can inform other unrelated disciplines. In particular, they have studied the end of semester crit, and the weekly practice of the desk-crit (a less formal review of ongoing project work normally conducted at the desk of the student as opposed to the formal review of the crit). They refer to this practice as a quintessential character of the signature pedagogy of the studio. Of particular interest to this research is how they note that the traditional modes of the crit (as a public presentation) and the desk-crit (as a private conversation with a tutor) facilitate multiple synchronous experiences, potentially by the whole class of students and by all academic staff at once. It is noted that "design work is generally presented in a visual medium, which can make it quicker to comprehend and assess and easier for multiple people to experience the same piece of work simultaneously" (Shrand \& Eliason, 2011, p. 60). 
This idea of the crit and the desk-crit as being significant characteristics of the signature pedagogy is widely supported (Mewburn, 2012), as is the view that such practice is common and similar in many different fields of design (Shrand \& Eliason, 2011). Despite the widespread nature of this pedagogical practice, there is still a lack of in-depth studies of the pedagogy of the design studio and the crit and the desk-crit (Mewburn, 2012).

\section{Modes and technologies of delivery}

Media environments do not cause learning, cognitive processing by the learner causes learning.

(Mayer, 2003, p. 137)

Given that "what students learn is inextricably embedded in how they learn," the modes of delivery and presentation that we as teachers provide to them have a major impact on their ability to learn (Laurillard \& McAndrew, 2002). Effective learning environments are constructed from a range of modes that respond to student learning styles, seek to align activities and learning outcomes, enable student to construct their own understandings and knowledge, engage in multimedia, and optimise the pedagogical benefits of each mode. A constructivist theory of learning is concerned with the ways in which a student constructs knowledge and meaning based on experiences and how the student organises such experiences into mental models (Jonassen \& Reeves, 1996). As such, constructivists are very concerned with the learning environments that they create for their students; the places in which experiences occur and the modes of delivery and technologies used.

The theory of situated learning is supportive of a constructivist theory in that the context of the learning activity is a vital ingredient in the learning experience (Laurillard, 2002). What a student comes to know is related to how they come to know, which is linked to the environment in which they are actively engaged. This relationship between what and how has been explored by Laurillard and McAndrew (2002) who related this to conceptual knowledge and procedural knowledge. These two cannot be separated and a significant aspect of the situation of learning will be the mode of delivery and the technologies used.

In selecting an appropriate mode of delivery, consideration should be given to facilitating the appropriate activities and constructing the appropriate situations in which a student may develop their understanding. Constructive alignment of activity, situation and mode (along with learning objectives and assessment) supports deep learning. Biggs' (1996, 1999) work on constructive alignment shows that student activity is vitally important in achieving desirable learning outcomes. It follows that aligning the mode of delivery with the learning outcomes is vital. The aim of a learning environment is that students will "actively construct ideas and generate meaning from sensory input by interpreting the input on the basis of previous experience" (Posner, cited in Toohey, 1999, p. 55). Such sensory input may take many forms through a range of different modes of delivery. This has more recently become modes that integrate digital technologies which provide "opportunities for students to engage in active processing and questioning of ideas, and practice thinking skills" (Toohey, 1999, p. 58); the kind of thinking that leads to learning.

\section{On-line learning}

Chen and You (2002) identified the advantages of internet-based technologies: access to resources, new tools and methods, easier interaction and communication, and multimodal presentations and learning. Similarly, Reffat (2007) identified the benefits of: improved explorative learning, electronic communications, archiving and access, synchronous and asynchronous communications, extended collaborations times and locations, and a potential strengthening of social bonds. Other researchers have identified similar potentials from new technologies (Bender \& Vredevoogd, 2006; Laiserin, 2002). 
On the specific mode of computers and on-line delivery, issues of networked learning and communication and interaction have already been discussed, but the basic advantages of distance learning, asynchronous learning, interactivity, theory and application, and self-motivation should not be overlooked. In particular, such interactivity enhances the ability of students to build semantic networks and construct their own understanding and knowledge (Jonassen \& Reeves, 1996). Computers and cyberspace are student-controlled environments and, as such, allow greater levels of student-led active collaboration in creating meaning. They also require greater levels of self-motivation and autonomy and are therefore not suited to all students for all activities (Mason, 2006; Saghafi, Franz, \& Crowther, 2012). There are also recognisable limitations of both synchronous and asynchronous communication, prompting Mason (n.d.) to promote flexibility and pansynchronous delivery modes. Online learning engages well with multimedia and this mix of text, image and audio can "provide enormous enrichment to the methodology of teaching, learning and learning by doing (Horne \& Henkel, 2004). It cannot yet, however, provide a reliable tactile learning experience as a form of intrinsic feedback (Laurillard, 2002) such as can be experienced in laboratory or workshop modes of delivery (Mason, 2006).

Contemporary design studios already rely heavily on modes of delivery that accommodate multimedia. Because the multimedia studio mode situates students in an authentic context, it also scaffolds them into learning the "language" of the discipline (Laurillard, 2002) as part of the signature pedagogy. Knowledge is "encoded visually or verbally in the symbol systems enabled by various technologies" (Jonassen \& Reeves, 1996, p. 693), and, in architectural education, those symbols are largely drawings and therefore require appropriate modes of delivery for visual dialogue to occur. This reliance on multimedia should encourage the integration of new digital technologies.

For any given learning objective, it is unlikely that a single technology or mode of delivery will be fully effective activities (Saghafi, Franz, \& Crowther, 2012). As noted earlier, the studio has advantages and problems as a learning environment, so there will be no single way in which to incorporate technology; rather a mix or blend that optimises the previously noted advantages while limiting the shortcomings. Mason (n.d.) noted that "there is no perfect medium" and multiple modes will be required to achieve optimal learning outcomes. Consideration of a range of pedagogical issues suggests blended environments in which "exposure to ideas through several different media [modes] definitely improves understanding and assimilation" (Mason, 2006, p. 13). In an architectural design context, Reffat (2007) referred to such blended environments as "augmented design studios," wherein a range of on-line activities support the more traditional modes of lectures and tutorials (studios). In summary, technologies and modes of delivery must align with learning objectives and create active learning environments in which students can construct their own knowledge.

\section{The technological possibilities and affordances of the design studio}

We can now take an understanding of the signature pedagogy of the design studio and analyse it to identify opportunities for technological enhancement drawing on some well-established and widely accepted models. Firstly, Delahaye (2005) provided a useful structure for understanding the activities of the design project as a component of the signature pedagogy of the studio. The seven steps for a successful project are:

1. Project is explicitly defined

2. Visit the work situation, review the context and stakeholders

3. Theories and concepts are reviewed

4. Critical thinking, action, and critical reflection

5. Discussions with teacher and learning group (students)

6. Repeat steps 1 to 5 (in any order)

7. Produce report

Second, we can also take Laurillard's (2002) understanding of learning through a conversational framework which identifies twelve interactions between teacher and student, and between 
conceptions and actions, which together form a complete map of a dialogue of learning (see Figure 1). Laurillard (2008) has proposed that the conversational framework may be used to test pedagogical activities for optimal learning experience - a procedure that has already been used to analyse some aspects of the studio (Crowther, 2010). To achieve a "complete learning process" (Laurillard, 2008, p. 142), all interactions must be present.

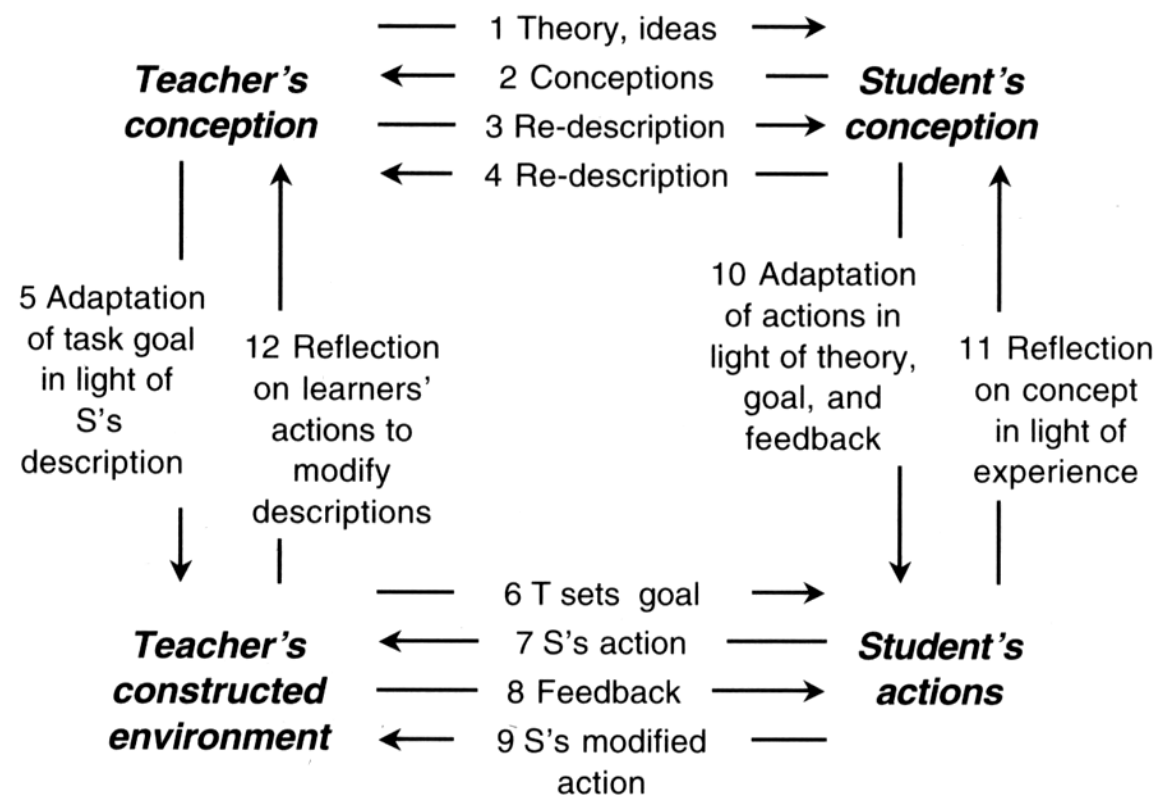

Figure 1. The 12 steps of the conversational model (Laurillard, 2002, p. 87)

Further to this, and finally, Laurillard (2002) has proposed a framework for analysing education media and their relationship to modes of delivery. Through this framework, she has identified five principal forms of media: narrative, interactive, communicative, adaptive and productive; and proposes appropriate methods and technologies for those media forms (Laurillard, 2002). She also identifies five fundamental types of learning activities: apprehending, exploring and investigating, discussing and debating, experimenting, and synthesising. She then aligns these learning activities with the forms of media that are most suited to supporting them: narrative with apprehending, interactive with exploring and investigating, communicative with discussing and debating, adaptive with experimenting, and productive with synthesising (Laurillard, 2002, p. 90).

If we also map these five fundamental types of learning activities to the seven stages of a design project and to the conversational framework, we can identify at what points in the pedagogical pattern of the studio project these activities are occurring, and therefore at what points certain methods and technologies will be most suited. Table 1 aligns the activities of Laurillard's (2002) framework with the seven steps of the project development (Delahaye, 2005) adding suggested technologies, we start to develop a type of pedagogical pattern as a learning design for the studio. 
Table 1

Stages of a pedagogical pattern for a design project compared with the twelve activities of a conversational framework; identifying opportunities for technological enhancement

\begin{tabular}{|c|c|c|c|c|}
\hline & $\begin{array}{l}\text { Seven steps for a } \\
\text { learning project } \\
\text { (Delahaye, 2005) }\end{array}$ & $\begin{array}{l}\text { Twelve activities from } \\
\text { the conversational } \\
\text { framework } \\
\text { (Laurillard, 2002) }\end{array}$ & $\begin{array}{l}\text { Learning activity } \\
\text { (Laurillard, 2002) }\end{array}$ & $\begin{array}{l}\text { Media form, and } \\
\text { appropriate methods } \\
\text { and technologies }\end{array}$ \\
\hline 1. & $\begin{array}{l}\text { Project is explicitly } \\
\text { defined }\end{array}$ & $\begin{array}{l}\text { (1) teacher's theory, } \\
\text { ideas; and, (6) teacher } \\
\text { sets goal }\end{array}$ & Apprehending & $\begin{array}{l}\text { Narrative: Print, TV, } \\
\text { video, DVD }\end{array}$ \\
\hline 2. & $\begin{array}{l}\text { Visit the work } \\
\text { situation, review } \\
\text { the context and } \\
\text { stakeholders }\end{array}$ & $\begin{array}{l}\text { (10) student's } \\
\text { adaptation of actions in } \\
\text { light of theory, goal, } \\
\text { and feedback }\end{array}$ & $\begin{array}{l}\text { Exploring and } \\
\text { investigating }\end{array}$ & $\begin{array}{l}\text { Interactive: Library, } \\
\text { CD, DVD, Web } \\
\text { resources }\end{array}$ \\
\hline 3. & $\begin{array}{l}\text { Theories and } \\
\text { concepts are } \\
\text { reviewed }\end{array}$ & $\begin{array}{l}\text { (2) student's } \\
\text { conceptions; and (11) } \\
\text { student's reflection on } \\
\text { concept in light of } \\
\text { experience }\end{array}$ & $\begin{array}{l}\text { Exploring and } \\
\text { investigating }\end{array}$ & $\begin{array}{l}\text { Interactive: Library, } \\
\text { CD, DVD, Web } \\
\text { resources }\end{array}$ \\
\hline 4. & $\begin{array}{l}\text { Critical thinking, } \\
\text { action, and critical } \\
\text { reflection }\end{array}$ & (7) student's action & Experimenting & $\begin{array}{l}\text { Adaptive: Laboratory, } \\
\text { field trip, simulation }\end{array}$ \\
\hline 5. & $\begin{array}{l}\text { Discussions with } \\
\text { teacher and } \\
\text { learning group } \\
\text { (students) }\end{array}$ & $\begin{array}{l}\text { (5) adaptation of task } \\
\text { goal in light of } \\
\text { student's description; } \\
\text { (8) feedback from } \\
\text { teacher; (9) student's } \\
\text { modified action; and } \\
\text { (12) reflection on } \\
\text { learners' action to } \\
\text { modify descriptions }\end{array}$ & $\begin{array}{l}\text { Discussing and } \\
\text { debating }\end{array}$ & $\begin{array}{l}\text { Communicative: } \\
\text { Seminar, on-line } \\
\text { conference }\end{array}$ \\
\hline 6. & $\begin{array}{l}\text { Repeat steps } 1 \text { to } \\
5 \text { (in any order) }\end{array}$ & $\begin{array}{l}\text { (3) teacher's re- } \\
\text { description; and (4) } \\
\text { student's re- } \\
\text { description }\end{array}$ & $\begin{array}{c}\text { (as above, steps } 1 \text { to } \\
5 \text { ) }\end{array}$ & $\begin{array}{l}\text { (as above, steps } 1 \text { to } \\
5 \text { ) }\end{array}$ \\
\hline 7. & Produce report & $\begin{array}{l}\text { (9) student's modified } \\
\text { action }\end{array}$ & Synthesising & $\begin{array}{l}\text { Productive: Essay, } \\
\text { product, animation, } \\
\text { model }\end{array}$ \\
\hline
\end{tabular}

While Table 1 does not provide a detailed analysis of the full range of new and digital technologies (an analysis that would be outdated as soon as it were published), it does provide a framework that is tailored to the signature pedagogy of design education, as a form of learning design or pedagogical pattern that may be used to assist in developing appropriate technological enhancements for the studio. That is to say it offers generic guidance as the most appropriate types of media and technologies at different stages of the design studio project.

For example, at the fifth stage of "discussions with teacher and learning group (students)," it will be possible to implement technologies that enhance "discussion and debate" through modes such as online seminars and conferences. Appropriate integration of such technologies would ideally help to avoid the previously discussed problems of the crit and its "hidden curriculum" while still enhancing the possibilities for dialogue and engagement. 


\section{Conclusion}

The benefits of new and digital technologies in the studio have been investigated and discussed by other researchers, though not with any proposition for their strategic implementation, nor within a structured learning design. This paper, through the preceding analysis of the studio and proposition of a learning design for the signature pedagogy of the studio, seeks to present a framework or structure within which educators can make more informed decisions about the appropriate implementation of new and digital technologies. Through this they may take the fullest advantages of the benefits on offer, as appropriate to this context of design; maximising the advantages and limiting the shortcomings of studio pedagogy.

The learning design or pedagogical pattern proposed in Table 1 is offered as a guide to understanding the learning activities of the studio and the media forms most appropriate for those activities. This proposed pattern may however have application in broader educational contexts beyond design. Laurillard (2012) proposed that signature pedagogies should, through the use of pedagogical patterns be transferable to other disciplines. There is a definite potential for the pedagogy of the design studio to have wider application in other unrelated disciplines and professions (Ochsner, 2000).

The signature pedagogy of the design studio is of course only one pedagogical pattern used in design education, albeit the dominant one. It is for this reason that a simple proposition of which technologies are "good" and which are not is not appropriate. This paper therefore stops short of such suggestions, but instead offers structured guidance for the reader and educator to make their own informed assessment of possible technologies for their own unique adaptation of the signature pedagogy of design education.

\section{References}

Bendar, D.M., \& Vredevoogd, J.D. (2006). Using online educational technologies to support studio instruction. Educational Technology \& Society, 9(4), 114-122.

Biggs, J. (1996). Enhancing teaching through constructive alignment. Higher Education, 32(3), 347-365.

Biggs, J. (1999). Teaching for quality learning at university: What the student does. Buckingham. UK: Open University Press.

Brindley, T., Doidge, C., \& Willmott, R. (2000). Introducing alternative formats for the design project review. In D. Nicol \& S. Pilling (Eds.), Changing Architectural Education: Towards a New Profession (pp. 108-115). London: E \& F N Spon.

Chen, W., \& You, M. (2008). Student response to an Internet-mediated industrial design studio course. International Journal of Technology and Design Education, 20(2), 151-174.

Crowther, P. (2010). Assessing architectural design processes of divergent learners. In Proceedings of the ATN Assessment Conference 2010: Sustainability, Diversity and Innovation, University of Technology, Sydney, NSW, December 2010. Australian Technology Network.

Delahaye, B. L. (2005). Human resource development: Adult learning and knowledge management. Brisbane, Australia: John Wiley and Sons Australia.

Dutton, T. A. (1987). Design and Studio Pedagogy. Journal or Architectural Education, 41(1), 1625.

Horne, G., \& Henkel, V. (2004). Application of multimedia in engineering design education. European Journal of Engineering Education, 29(1), 87-96.

Jonassen, D., \& Reeves, T. C. (1996). Learning with technology: Using computers as cognitive tools. In D. Jonassen (Ed.) Handbook of research for educational communications and technology: A project of the Association for Educational Communications and Technology (pp. 
706-707). New York: Macmillan Library Reference.

Laiserin, J. (2002). From atelier to e-telier: virtual design studios. Architectural Record, 190(1), 141-142.

Laurillard, D. (1997). Learning formal representations through multimedia. In F. Marton, D. Hounsell, \& N. Entwistle (Eds.). The Experience of Learning: Implications for Teaching and Studying in Higher Education (pp. 172-183). Edinburgh, Scotland: Scottish Academic Press.

Laurillard, D. (2002). Rethinking University Teaching: a framework for the effective use of learning technologies $\left(2^{\text {nd }}\right.$ ed.), London: Routledge Falmer.

Laurillard, D. (2008). The teacher as action researcher: Using technology to capture pedagogic form. Studies on Higher Education, 33(2), 139-154.

Laurillard, D. (2012). Teaching as a design science: Building pedagogical patterns for learning and technology. New York: Routledge.

Laurillard, D., \& McAndrew, P. (2002). Virtual teaching tool: Bringing academics closer to the design of e-learning. In S. Banks, P. Goodyear, V. Hodgson and D. McConnell (Eds.) Network Learning 2002: A Research Based Conference on e-Learning in Higher Education and Lifelong Learning (pp. 11-16). Retrieved from http://kn.open.ac.uk/public/document.cfm?docid=7243

Marton, F., Dall'Alba, G., \& Beaty, E. (1993). Conceptions of learning. International Journal of Educational Research, 19(3), 277-300.

Marton, F., \& Säljö, R. (1976). On qualitative differences in learning: I - Outcome and process. British Journal of Educational Psychology, 46(1), 4-11.

Mason, R. (n.d.). The globalisation of education. Retrieved from http://iet.open.ac.uk/pp/r.d.mason/globalbook/syncasync.html

Mason, R. (2006). The university - current challenges and opportunities. In S. D’Antoni \& G. Hermes, (Eds.). The Virtual University: Models \& Messages, Lessons from Case Studies. UNESCO. Retrieved from http://www.unesco.org/iiep/virtualuniversity/home.php\#challenges

Mayer, R. E. (2003). The promise of multimedia learning: using the same instructional design methods across different media. Learning and Instruction, 13(2), 125-139.

McInnis, C, James, R., \& Hartley, R. (2000). Trends in first year experience. Retrieved from http://www.dest.gov.au/archive/highered/eippubs2000.htm

Mewburn, I. (2012). Lost in translation: Reconsidering reflective practice and design studio pedagogy. Arts and Humanities in Higher Education, 11(4), 363-379.

Mostafa, M., \& Mostafa, H. (2010). How do architects think? Learning styles and architectural education. International Journal or Architectural Research, 4(2-3), 310-317.

Nicol, D., \& Pilling, S. (2000). Architectural education and the profession. In D. Nicol \& S. Pilling (Eds.), Changing Architectural Education: Towards a New Profession (pp. 1-22). London: E \& F N Spon.

Ochsner, J. K. (2000). Behind the mask: a psychoanalytic perspective on interaction in the design studio. Journal of Architectural Education, 53(4), 194-206.

Ramsden, P. (2003). Learning to teaching in higher education ( $2^{\text {nd }}$ ed.). London: Routledge Falmer.

Reffat, R. (2007). Revitalizing architectural design studio teaching using ICT: Reflections on practical implications. International Journal of Education and Development using Information and Communication Technology, 3(1), 39-53.

Rohse, S., \& Anderson, T. (2006). Design patterns for complex learning. Journal of Learning Design, 1(3), 82-91. 
Saghafi, M. R., Franz, J., \& Crowther, P. (2012). A holistic blended design studio model: a basis for exploring and expanding learning opportunities. In Society for Information Technology and Teacher Education International Conference (SITE 2012), Austin, Texas: EdITLib.

Schön, D. A. (1984). The architectural studio as an exemplar of education for reflection-in-action. Journal of Architectural Education, 38(1), 2-9.

Schrand, T, \& Eliason, J. (2011). Feedback practice and signature pedagogies: what can the liberal arts learn from the design critique? Teaching in Higher Education, 17(1), 51-62.

Shreeve, A., Sims, E. A. R., \& Trowler, P. A kind of exchange: learning from art and design teaching. Higher Education Research and Development, 29(2), 125-138.

Shulman, L. S. (2005). Signature pedagogies in the professions. Daedalus, 134(3), 52-59.

Stevens, G. (1998). The favored circle: The social foundations of architectural distinction. Cambridge: MIT Press.

Taylor, S. S. (2009). Effects of studio space on teaching and learning: Preliminary findings from two case studies. Innovative Higher Education, 33(4), 217-228.

Toohey, S. (1999). Designing courses for higher education. Buckingham, UK: Society for Research into Higher Education/Open University.

\section{Copyright @ 2013 Phillip Crowther}

